\title{
PHENOLIC COMPOSITION AND ANTIOXIDANT PROPERTIES OF ANZER HONEY FROM BLACK SEA REGION OF TURKEY
}

\author{
Türkiye'nin Karadeniz Bölgesinden Anzer Balının Fenolik Bileşimi ve Antioksidan \\ Özellikleri
}

\begin{abstract}
Meltem MALKOÇ ${ }^{1 *}$, Hilal ÇAKIR ${ }^{2}$, Yakup KARA², Zehra CAN ${ }^{3}$, Sevgi KOLAYLI²
${ }^{1}$ Karadeniz Technical University, Vocational School of Health Sciences, Trabzon, TURKEY, E-mail: meltemmalkoc69@gmail.com, ORCID No.:0000-0002-8652-941X

${ }^{2}$ Karadeniz Technical University, Department of Chemistry, Faculty of Sciences Trabzon, TURKEY, E-mail: hilalebruhotaman@gmail.com, ORCID No.: 0000-0003-2398-8106; E-mail: yakupkara@ktu.edu.tr, ORCID No. :00000003-3121-5023; E-mail: skolayli61@yahoo.com, ORCiD No.:0000-0003-0437-6139.

${ }^{3}$ Bayburt University, Faculty of Applied Sciences, Department of Emergency Aid and Disaster Management, Bayburt, TURKEY, E-mail: zcan@bayburt.edu.tr, ORCD No.:0000-0002-7156-4941

*Corresponding Author/Yazışma Yazarı: E-mail: meltemmalkoc69@gmail.com.
\end{abstract}

Geliş tarihi / Received: 06.08.2019 Kabul Tarihi / Accepted: 06.09.2019～DOI: https://doi.org/10.31467/uluaricilik.602906

\section{ABSTRACT}

Anzer honey is produced on the Anzer plateau, known for its rich flora, in the Eastern Black Sea region of Turkey. It is well known across the world, and is believed to be of high medical value.

This study is the first detailed research in which the polyphenolic profiles responsible for the bioactive properties of Anzer honey was determined, melissopalynological analysis was performed, and in which total phenolic contents (TPC), total flavonoid contents (TFC), and total antioxidant activities were identified. The ferric (III) reducing antioxidant power (FRAP) assay and 1,1-diphenyl-2picrylhydrasil (DPPH) free radical scavenging test were used to determine antioxidant activity. The total mean phenolic content of Anzer honey was $26.92 \mathrm{GAE} / 100 \mathrm{~g}$, and the total flavonoid content was $2.79 \mathrm{mgQE} / 100 \mathrm{~g}$. Anzer honeys' mean FRAP and DPPH values were $110.11 \mu \mathrm{moLTrolox} / 100 \mathrm{~g}$ and 49,12 $\mathrm{mg} / \mathrm{mL}$, respectively. The phenolic acids and flavonoids of Anzer honey were determined using highperformance liquid chromatography (HPLC). Of the 19 standard compounds used in the analysis, pinocembrin, hesperidin, chrysin, protocatechuic acid, $p$-coumaric acid, catechin, caffeic acid phenyl ester (CAPE), $p$-OH benzoic acid, and caffeic acid as major compounds, while myricetin, luteolin, rutin, resveratrol, epicatechin, $t$-cinnamic acid, ferulic acid, and gallic acid were identified as minor compounds. Daidzein and syringic acid were not detected. Based on these findings, Anzer is a flower honey noteworthy for the rich variety of its polyphenols.

Key words: Anzer honey, antioxidant, phenolics, flavonoids

\section{ÖZ}

Anzer balı, Türkiye'nin Doğu Karadeniz bölgesinde zengin bitki örtüsü ile ünlü Anzer platosunda üretilmektedir. Anzer balı dünyaca tanınan bir bal olup, tıbbi değerinin yüksek olduğuna inanılmaktadır. $\mathrm{Bu}$ çalışma Anzer balının biyoaktif özelliklerinden sorumlu polifenolik profilinin belirlendiği melissopalinolojik analiz, toplam fenolik madde, toplam flavonoid madde ve toplam antioksidan aktivitelerinin tespit edildiği ilk detaylı araştırmadır. Antioksidan aktivite demir (III) indirgeyici antioksidan güç testi (FRAP) ve 1,1-difenil-2-pikrilhidrazil (DPPH) serbest radikali temizleme testi ile ölçüldü. Anzer balının toplam fenolik içeriğinin ortalama $26.92 \mathrm{GAE} / 100 \mathrm{~g}$ ve toplam flavonoid madde miktarının $2.79 \mathrm{mg} \mathrm{QE} / 100 \mathrm{~g}$ olduğu tespit edildi. Anzer ballarının ortalama FRAP ve DPPH değerleri 


\section{ARAŞTIRMA MAKALESI / RESEARCH ARTICLE}

sırasıyla $110,11 \mu \mathrm{molTrolox} / 100 \mathrm{~g}$ ve $49,12 \mathrm{mg} / \mathrm{mL}$ olarak bulundu. Anzer balının fenolik asitleri ve flavonoidleri yüksek performanslı sıvı kromatografisi (HPLC) ile belirlendi. Analizde kullanılan 19 adet standart bileşikten daidzein ve şiringik asit hariç, pinosembrin, hesperidin, krisin, protokatekuik asit, p-kumarik asit, kateşin, kafeik asit fenil ester (CAPE), $p$-OH benzoik asit, kafeik asit major bileşen, mirisetin, luteolin, rutin, resveratrol, epikateşin, $t$-sinnamik asit, ferulik asit ve gallik asit ise minor bileşen olarak tespit edildi. Bu sonuçlara göre, Anzer balı içerdiği polifenolik maddelerin çeşitliliği bakımından dikkat çekici özelliğe sahip bir çiçek balıdır.

Anahtar kelime: Anzer balı, Antioksidan, Fenolikler, Flavonoidler

\section{GENIŞLETILMIŞ ÖZET}

Amaç: Anzer Doğu-Karadeniz Bölgesinde yer alan Rize-İkizdere ilçesine bağlı 2300 rakıma sahip bir yayla olup, çok zengin çiçek florası ile bilinmektedir. Bölgenin her 15 gün de bir değişen bitki florasından dolayı çok sayıda endemik ve endemik olmayan bitki türlerine ev sahipliği yapmaktadır. Bu coğrafya da üretilen Anzer balı Türkiye'de ve dünyada tanınan bir bal olup, tıbbi değerinin yüksek olduğuna inanılmaktadır. Anzer balı halk arasında farenjit, bademcik iltihabı, mide ülseri ve yara tedavisi gibi rahatsızlıklarda geleneksel olarak kullanılmaktadır. Sınırlı miktarda üretilen bu balın biyolojik aktif değeri ile ilgili bilimsel veriler çok sınırlıdır. Balın biyolojik değeri yapısında yer alan sekonder metabolitlerden ileri gelmektedir. Polifenoller balda bulunan en önemli sekonder metabolitler olup bu çalışmada Anzer balının polifenolleri araştırıldı. Elde edilen veriler literatürdeki çiçek balları ile karşılaştııılarak, Anzer balının farkı özelliklerinin ortaya çıkarılması amaçlandı.

Gereç ve Yöntem: Ekim 2018'de, Rize Tarım Kredi Kooperatifi (Türkiye) yardımıyla S.S. Çiçekli Köyü (Anzer) Anzer yaylasındaki arıcılardan 11 farklı Anzer balı örneği temin edildi. Bu etiketli balların melisopalinolojik analizi, toplam fenolik madde, toplam flavonoid madde miktarları, polifenolik kompozisyonları, antioksidan özellikleri belirlendi. Antioksidan aktivite, demir(III) indirgeyici antioksidan güç testi (FRAP) ve 1,1-difenil-2pikrilhidrazil (DPPH) serbest radikali temizleme testi ile ölçüldü Anzer ballarının yüksek performanslı sıvı kromatografisi (HPLC-UV) ile yapılan fenolik kompozisyon analizinde 19 adet fenolik standart bileşik (daidzein ve şiringik asit, pinosembrin, hesperidin, krisin, protokatekuik asit, $p$-kumarik asit, kateşin, kafeik asit fenil ester (CAPE), $p$-OH benzoik asit, kafeik asit, mrisetin, luteolin, rutin, resveratrol, epikateşin, $t$-sinamik asit, ferulik asit ve gallik asit) kullanıldı.

Bulgular: Mikroskobik olarak yapılan melissopalinolojik analiz sonucu Anzer balında hiç bir polenin \%45'in üzerinde olmadığı ve Lamiacea, Fabacea, Apiacea, Rocacea, Asteracea, Ericacea, Liliacea polenlerinin majör seviyede Thymus, Rumex, Onobrychis, Cistus, Plantago, Ranunculus, Rhododendron, Myosotis, Geranium polenlerinin ise minör seviyede olduğu tespit edildi. Anzer balının toplam fenolik madde miktarlarının 19,50 ile $38,30 \mathrm{mgGAE} / 100 \mathrm{~g}$ ve toplam flavonoid madde miktarları 2,03 ile 3,66 mgQE/100g arasında değişim gösterdiği bulundu. Numunelerin toplam antioksidan kapasitelerinin FRAP cinsinden 92,53 ile 124,33 umolTrolox/100g arasında ve serbest radikal temizleme aktivitesi (DPPH) 38,04 ile $64,12 \mathrm{mg} / \mathrm{mL}$ arasında olduğu tespit edildi. Balların fenolik bileşimlerinin analizi sonucunda anzer ballarında daidzein ve şiringik asit hariç sırasıyla pinosembrin, hesperidin, krisin, protokatekuik asit, $p$-kumarik asit, kateşin, kafeik asit fenil ester (CAPE), $p$-OH benzoik asit, kafeik asit major düzeyde, mirisetin, luteolin, rutin, resveratrol, epikateşin, $t$ sinnamik asit, ferulik asit ve gallik asit minör düzeyde tespit edildi.

Sonuç: Anzer balı içerdiği polifenolik maddelerin çeşitliliği bakımından dikkat çekici özelliğe sahip bir çiçek balı olup, bu zengin polifenolik içeriğin üretildiği bölgenin eşi emsali olmayan bitki florasından ileri geldiği düşünülmektedir. Balda majör seviyede bulunan pinosembrin, hesperidin ve krisin gibi flavonoid yapılı doğal bileşiklerin geniş spektrumlu biyolojik aktiviteleri bu balın tıbbi değerini artırmaktadır. 


\section{ARAŞTIRMA MAKALESI / RESEARCH ARTICLE}

\section{INTRODUCTION}

Anzer honey is particularly well known for its curative properties. It is also unique since it is produced from the nectar of approximately 500 flowers from the Anzer Plateau near İkizdere, Rize in the Eastern Black Sea region of Turkey (Tezcan et al. 2011). Depending on climatic conditions, Apis melifera bees collect the honey from July to August in general. Although Anzer honey predominantly contains Thymus spp, various secondary and trace pollen grains from other plants have also been identified. The mixed pollen grains largely consist of Thymus spp, Campanula spp, Trifolium spp, Geranium spp, Lotus spp, Salvia officinalis, Heracleum spp, Myosotis spp, and Lamium spp (Sorkun et al. 1989). This heterofloral honey is the best known and most expensive honey in Turkey and is produced in very limited quantities. Another reason for the high value of Anzer honey is that the bees in the region are Caucasian bees (Apis mellifera caucasica). Local in habitants believe that Anzer honey can be used in the treatment of pharyngitis, tonsillitis, ulcers, wounds and abrasions (Şekeroğlu et al. 2007). These are more docile, coldresistant and industrious than other bees and can collect nectar from deep tube flowers using their long proboscis (Kara et al. 2012). The medicinal property of honey results from the presence of various secondary molecules, mostly phenolic compounds, such as phenolic acids and flavonoids. Polyphenols are responsible for biological properties such as antioxidant, antimicrobial, antiviral, antifungal and anticarcinogenic and anti-diabetic activity (Cianciosi et al. 2018). In addition to sugars, all honeys contain numerous organic acids, proteins, $\mathrm{SH}$-containing amino acids, a-tocopherol, ascorbic acid, phenolic acids, flavonoids, anthocyanin, and honey enzymes (Deng et al. 2018; Vasićet et al. 2019). Composition of honey may vary depending on the flora, the geographical region, and the time of harvest. Relatively few studies have investigated the antioxidant properties of Anzer honey. Anzer honey has been reported to protect the rat stomach against ethanol-induced increased vascular permeability, which may be associated with its ascorbic acid content (Doğan and Kolankaya 2005). Another study reported that Anzer honey possesses a high antioxidant capacity with an efficient sulfhydryl source, and exhibits a marked protective effect against hepatic injury in rats (Korkmaz and Kolankaya 2009). In another study of Anzer honey, sugar and organic acid composition were reported, but phenolic compositions were not mentioned (Tezcan et al. 2011). Therefore, since there is not enough information about the content of Anzer honey in the literature, especially secondary metabolites, polyphenolic composition and antioxidant properties of the honey was evaluated.

\section{MATERIALS AND METHODS}

\section{Chemicals}

The chemical standards employed were all HPLCgrade pure. The common phenolic compounds were supplied by Sigma-Aldrich (Munich, Germany). 2,4,6-Tripyridyl-s-triazine (TPTZ), Folin-Ciocalteu's phenol reagent, 1,1-diphenyl-2-picrylhydrazyl (DPPH), and Trolox (6-hydroxy-2,5,7,8tetramethylchroman-2-carboxylic acid) were supplied by Sigma Chemical Co. (St Louis, MO, USA). Acetonitrile, methanol and ethanol were purchased from Sigma-Aldrich Co. (St. Louis, MO, USA). UV-VIS Spectrophotometer (Thermo Scientific Evolution TM 201, USA) was used in all absorbance measurements.

\section{Honey Samples}

Eleven Anzer honey samples were obtained from the beekeepers on the Anzer Plateau in October, 2018. Melissopalynological characterization was performed using the standardized technique developed by Louveaux et al. (1978). In this method, pollen was classified according to percentages; dominant pollen constituting $45 \%$ or more of the total pollen grains, secondary pollen (16-44\%), important minor pollen (3-15\%), or minor pollen (less than $3 \%)$. Briefly, approximately $5 \mathrm{~g}$ of honey sample was dissolved $(50 \mathrm{~mL})$ by the addition of $99 \%$ methanol. The mixture was continuously stirred with a shaker (Heidolph Promax 2020, Schwabach, Germany) at room temperature for 24 hours, and then sonicated for 4 hours with an ultrasonicator. The mixture passed through filter paper and concentrated in a rotary evaporator (IKA-Werke, Staufen, Germany) at $40^{\circ} \mathrm{C}$. The residue was redissolved in methanol and kept at $4^{\circ} \mathrm{C}$ until used for phenolic compound analysis (Çakır et al. 2018).

\section{Total Phenolic Content Measurement}

TPC were measured based on Folin-Ciocalteu's method (Singleton and Rossi. 1965) using gallic acid (GA) as standard. Firstly, $100 \mu \mathrm{L}$ of various concentrations of gallic acid and sample solutions were diluted with $500 \mu \mathrm{L} 0.2 \mathrm{~N}$ Folin-Ciocalteu 


\section{ARAŞTIRMA MAKALESII / RESEARCH ARTICLE}

reagent, than vortexed and incubation for $3 \mathrm{~min}$ and added $1.50 \mathrm{~mL}$ of $\mathrm{Na}_{2} \mathrm{CO}_{3}(2 \%)$. Following further vortexing, the mixture was incubated for $2 \mathrm{~h}$ at $20^{\circ} \mathrm{C}$ with occasional shaking. At the end of that time, the absorbance was measured at $760 \mathrm{~nm}$. TPC was expressed as mgGAE equivalents per $100 \mathrm{~g}$ of sample using a standard graph. All the measurements were performed in triplicate.

\section{Total Flavonoid Measurement}

TFC were calculated by means of a spectrophotometric method using quercetin as standard (Fukumoto and Mazza 2000). Briefly, 500 $\mu \mathrm{L} \mathrm{mL}$ of quercetin $(1,0.5,0.25,0.125,0.0625$, and $0.03125 \mathrm{mg} / \mathrm{mL}$ ) and $0.5 \mathrm{~mL}$ samples, $100 \mu \mathrm{L}$ of $10 \%$ Al $\left(\mathrm{NO}_{3}\right)_{3}$ and $100 \mu \mathrm{L}$ of $1 \mathrm{M} \mathrm{NH}_{4} . \mathrm{CH}_{3} \mathrm{COO}$ were added to a test tube. This mixture was incubated at room temperature for $40 \mathrm{~min}$ and the absorbance was measured against a blank at $415 \mathrm{~nm}$. The TFC was calculated as $\mathrm{mg}$ of quercetin equivalents per $100 \mathrm{~g}$ honey sample.

\section{Ferric Reducing/Antioxidant Power Assay}

The antioxidant properties of the different honeys samples were assessed using the method described by Benzie and Strain (1996). The reducing power ability of ferric tripyridyltriazine (Fe-III-TPTZ) complex (FRAP) method relies on the calculation of samples' iron-reducing capacities. The FRAP reagent consisted of a mixture of $25 \mathrm{~mL}$ of $300 \mathrm{mM}$ acetate buffer, with $2.5 \mathrm{~mL}$ of $10 \mathrm{mM}$ TPTZ solution in $40 \mathrm{mM} \mathrm{HCl}$ and $2.5 \mathrm{~mL}$ of $20 \mathrm{mM} \mathrm{FeCl}{ }_{3} \cdot 6 \mathrm{H}_{2} \mathrm{O}$ solution. Next, $300 \mu \mathrm{L}$ freshly prepared FRAP reagent was mixed with $100 \mu \mathrm{L}$ of honey sample prior to incubation for $4 \mathrm{~min}$ at $37^{\circ} \mathrm{C}$. The last absorbance was read at $595 \mathrm{~nm}$ against reagent blank with distilled water. Trolox was employed as a positive control to produce a reference curve $(62,5-$ $1000 \mu \mathrm{M})$. FRAP values were expressed as $\mu \mathrm{M}$ Trolox equivalent of $g$ honey. Higher FRAP values were regarded as indicating a greater antioxidant capacity.

\section{DPPH Radical-Scavenging Activity}

The radical scavenging activity of the methanolic honey samples was determined using the 1,1- diphenyl-2-picrylhydrasil (DPPH) radical assay. This technique relies on measuring the change from purple to yellow that takes place in the DPPH solution as the radical is neutralized by the antioxidants (Molyneux 2004). Briefly, varying concentrations of $0.75 \mathrm{~mL}$ of honey extracts were combined with $0.75 \mathrm{~mL}$ of $0.1 \mathrm{mM}$ of DPPH in methanol. The resulting mixture was stored in a lightless environment for $30 \mathrm{~min}$, after which the absorbance at $517 \mathrm{~nm}$ was measured using a spectrophotometer. Trolox was used as standard, and the radical scavenging activity of DPPH was expressed as $\mathrm{SC}_{50}$, defined as the concentration $(\mathrm{mg} / \mathrm{mL})$ needed to inhibit $50 \%$ of the free radical scavenging activity. $\mathrm{SC}_{50}$ values are calculated using linear regression analysis, lower values indicating greater antioxidant activity.

\section{RP-HPLC Analysis and Sample Preparation}

Firstly, the methanolic residue was dissolved in 15 $\mathrm{mL}$ acidified distilled water $(\mathrm{pH} 2)$. Liquid-liquid extraction was carried out with $5 \times 3 \mathrm{~mL}$ diethyl ether and $5 \times 3 \mathrm{~mL}$ ethyl acetate, consecutively. Both diethyl ether and ethyl acetate phases were incorporated and dried by rotary evaporation (IKAWerke, Staufen, Germany) at $40^{\circ} \mathrm{C}$. The pellet was resuspended in $2 \mathrm{~mL}$ methanol, filtered with syringe filters (RCmembrane, $0,45 \mu \mathrm{m}$ ), and injected to HPLC (Elite LaChrom Hitachi, Japan). Each specimen was injected into the HPLC system with a reverse phase C18 column (150 mm 4,6 mm, $5 \mathrm{~mm}$; Fortis) at 280 and $340 \mathrm{~nm}$. The mobile phase consisted of (A) $2 \%$ acetic acid in water and (B) acetonitrile: water (70:30). The sample injection volume was $20 \mu \mathrm{L}$. The column temperature was set at $30^{\circ} \mathrm{C}$, and the flow rate at $1,5 \mathrm{~mL} / \mathrm{min}$. The programmed solvent began with a linear gradient held at $95 \% \mathrm{~A}$ for $3 \mathrm{~min}$, decreasing to $80 \% \mathrm{~A}$ at 10 min, $60 \% \mathrm{~A}$ at $20 \mathrm{~min}, 20 \% \mathrm{~A}$ at $30 \mathrm{~min}$ and finally $95 \% \mathrm{~A}$ at $50 \mathrm{~min}$. A standard chromatogram for the 19 phenolic standards (gallic acid, protocatechuic acid, $p-\mathrm{OH}$ benzoic acid, catechin, caffeic acid, syringic acid, epicatechin, $p$-coumaric acid, ferulic acid, rutin, myricetin, resveratrol, daidzein, lutein, $t$ cinnamic acid, hesperidin, chrysin, pinocembrin, and CAPE) applied at HPLC-UV is shown in Figure 1 (Çakır et al. 2018). 


\section{ARAŞTIRMA MAKALESI / RESEARCH ARTICLE}

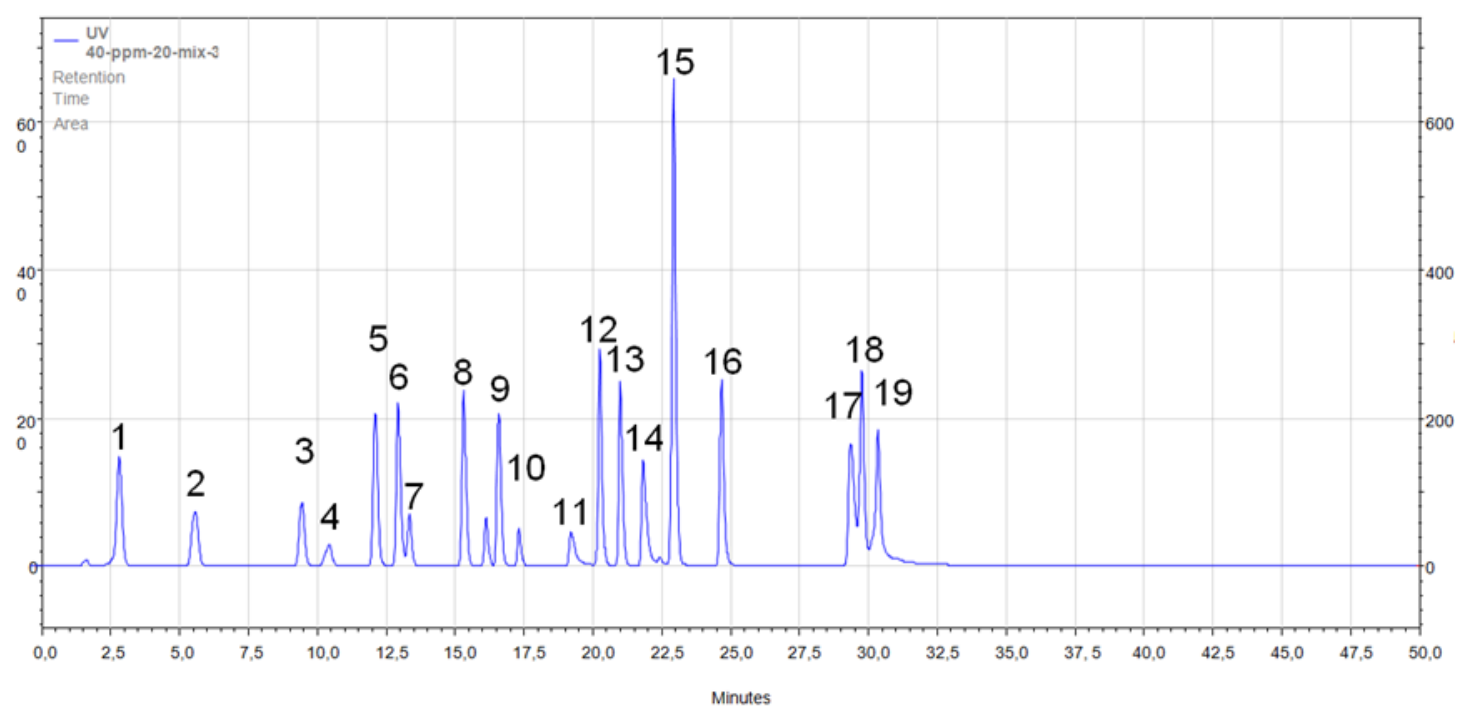

Figure 1. HPLC-UV chromatograms of phenolic standards

Şekil 1. Fenolik standartların HPLC-UV kromatogramları

1. Gallic acid, 2. Protocatechuic acid 3. p-OH Benzoic acid, 4. Catechin, 5. Caffeic acid, 6. Syringic acid, 7. Epicatechin, 8. p-Coumaric acid, 9. Ferulic acid, 10. Rutin 11. Myricetin, 12. Resveratrol, 13. Daidzein, 14. Luteolin, 15. t-Cinnamic acid, 16. hesperidin, 17. Chrysin, 18. Pinocembrin, 19. CAPE.

\section{RESULTS}

Melissopalynological findings of the study is showed that the honeys contained pollens from different family types at levels less than $45 \%$, including Lamiacea, Fabacea, Apiacea, Rocacea, Asteracea, Ericacea, And Liliacea. The major pollens detected in the honey samples were Thymus, Rumex, Onobrychis, Cistus, Plantago, Ranunculus, Rhododendron, Myosotis, and Geranium.

Total phenolic contents, total flavonoids and antioxidant results are given in Table I. TPC ranged from 19.50 to $38.30 \mathrm{mg} \mathrm{GAE} / 100 \mathrm{~g}$ honey, and the mean value was determined as $26.92 \mathrm{mg}$ $\mathrm{GAE} / 100 \mathrm{~g}$. Flavonoids, an important subclass of polyphenols, were also measured as totally in the honey samples, the results were ranged from 2.03 to $3.66 \mathrm{mg} \mathrm{QE} / 100 \mathrm{~g}$ and a mean value of $2.79 \mathrm{mg}$ $\mathrm{QE} / 100 \mathrm{~g}$. FRAP ranged from 92.53 to 124.33
umolTrolox/100 $\mathrm{g}$ and the mean value was determined as $110.11 \mu$ molLTrolox/100g. DPPH ranged from 35.30 to $64.12 \mathrm{mg} / \mathrm{mL}$, and a mean value of $49.12 \mathrm{mg} / \mathrm{mL}$ (Table 1).

Nineteen phenolic standards were used to measure the phenolic profiles of the honey samples with UVHPLC, and all standards except for syringic acid and daidzein were detected at different concentrations. High levels of pinocembrin, hesperidin and chrysin were detected, together with moderate levels of protocatechuic acid, $p$-coumaric acid, catechin, caffeic acid phenyl ester (CAPE), $p$-OH benzoic acid and caffeic acid, and lower levels of epicatechin, rutin, $t$-cinnamic acid, gallic acid, myricetin, luteolin, ferulic acid, and resveratrol. The results are given in Table 2. 


\section{ARAŞTIRMA MAKALESI / RESEARCH ARTICLE}

Table 1. Phenolic contents of the Anzer honey

Tablo1. Anzer balının fenolik içeriği

\begin{tabular}{lllll}
\hline & $\begin{array}{l}\text { Total phenolic } \\
(\mathbf{m g ~ G A E} / \mathbf{1 0 0 g})\end{array}$ & $\begin{array}{l}\text { Total flavonoid } \\
(\mathbf{m g ~ Q E} / 100 \mathrm{~g})\end{array}$ & $\begin{array}{l}\text { FRAP } \\
(\boldsymbol{\mu m o l T r o l o x} / \mathbf{1 0 0 g})\end{array}$ & $\begin{array}{l}\text { DPPH-SC }_{\mathbf{5 0}} \\
(\mathbf{m g} / \mathbf{m L})\end{array}$ \\
\hline A1 & $30.10 \pm 0.45$ & $3.56 \pm 0.22$ & $123.20 \pm 5.20$ & $35.30 \pm 0.30$ \\
A2 & $24.90 \pm 0.30$ & $3.03 \pm 0.00$ & $108.10 \pm 1.56$ & $61.20 \pm 0.50$ \\
A3 & $38.30 \pm 0.58$ & $3.66 \pm 0.10$ & $124.33 \pm 4.20$ & $38.04 \pm 0.50$ \\
A3 & $25.90 \pm 0.70$ & $2.72 \pm 0.10$ & $112.12 \pm 2.20$ & $57.31 \pm 0.55$ \\
A5 & $29.10 \pm 4.30$ & $2.74 \pm 0.10$ & $113.20 \pm 3.44$ & $53.80 \pm 0.50$ \\
A6 & $23.10 \pm 0.30$ & $3.05 \pm 0.02$ & $92.53 \pm 1.88$ & $64.12 \pm 0.80$ \\
A7 & $24.20 \pm 1.20$ & $2.50 \pm 0.03$ & $112.07 \pm 2.06$ & $54.04 \pm 0.60$ \\
A8 & $25.10 \pm 0.10$ & $2.50 \pm 0.04$ & $118.08 \pm 3.58$ & $40.52 \pm 0.01$ \\
A9 & $34.10 \pm 3.70$ & $2.54 \pm 0.10$ & $109.50 \pm 4.80$ & $46.90 \pm 0.60$ \\
A10 & $19.50 \pm 0.20$ & $2.03 \pm 0.10$ & $95.10 \pm 3.07$ & $42.20 \pm 0.01$ \\
A11 & $21.80 \pm 0.24$ & $2.44 \pm 0.04$ & $103.00 \pm 3.42$ & $50.0 \pm 0.50$ \\
\hline Mean \pm SD & $26,92 \pm 5,46$ & $2,79 \pm 0,49$ & $110,11 \pm 10,21$ & $49,12 \pm 9,21$ \\
\hline
\end{tabular}

Table 2. Phenolic profiles of the Anzer honeys

Tablo 2. Anzer balının fenolik profile

\begin{tabular}{lllllllllllll}
\hline $\begin{array}{l}\text { Standards } \\
(\boldsymbol{\mu g} / \mathbf{1 0 0 g})\end{array}$ & A1 & $\mathbf{A 2}$ & $\mathbf{A 3}$ & $\mathbf{A 4}$ & $\mathbf{A 5}$ & $\mathbf{A 6}$ & $\mathbf{A 7}$ & $\mathbf{A 8}$ & $\mathbf{A 9}$ & $\mathbf{A 1 0}$ & $\mathbf{A 1 1}$ & $\mathbf{X} \mathbf{S D}$ \\
\hline Gallic Acid & 89 & 26 & - & 27 & - & 28 & 42 & - & 24 & 42 & 15 & $20 \pm 16$ \\
Protocathequic & 560 & 33 & 804 & 626 & 1601 & 763 & 670 & 2155 & 478 & 506 & 193 & $853 \pm 583$ \\
Acid & & & & & & & & & & & & \\
$p$-OH Benzoic Acid & 96 & 125 & 131 & 130 & 90 & 110 & 123 & 151 & 96 & 109 & 125 & $119 \pm 17$ \\
Catechin & 52 & 396 & 203 & 407 & 475 & 338 & 189 & 1200 & 300 & 208 & 825 & $450 \pm 320$ \\
Caffeic Acid & 25 & 185 & 128 & 100 & 087 & 153 & 136 & 92 & 85 & 088 & 66 & $110 \pm 37$ \\
Syringic Acid & - & - & - & - & - & - & - & - & - & - & - & - \\
Epicatechin & 52 & 276 & 018 & 079 & 008 & - & 17 & 28 & 20 & 1 & 20 & $47 \pm 83$ \\
p-Coumaric Acid & 63 & 1405 & 193 & 1230 & 177 & 1024 & 563 & - & 693 & 174 & 214 & $562 \pm 501$ \\
Ferulic Acid & 10 & 31 & 29 & 38 & 028 & 31 & 22 & 31 & 26 & 22 & 22 & $26 \pm 4$ \\
Rutin & - & 120 & 24 & 154 & 064 & 116 & 41 & - & 129 & 5 & - & $65 \pm 56$ \\
Myricetin & 61 & 34 & 60 & 88 & 104 & 112 & 39 & 130 & 55 & 204 & 88 & $96 \pm 22$ \\
Resveratrol & 51 & 32 & 19 & 44 & 67 & 80 & 34 & 90 & 28 & 69 & 32 & $49 \pm 23$ \\
Daidzein & - & - & - & - & - & - & - & - & - & - & - & - \\
Luteolin & 15 & 94 & 84 & 100 & 79 & 87 & 77 & 87 & 66 & 61 & 63 & $80 \pm 13$ \\
$t$-Cinnamic Acid & 4 & 65 & 16 & 54 & 20 & 42 & 40 & 33 & 23 & 13 & 32 & $34 \pm 16$ \\
Hesperidin & 9236 & 2810 & 4420 & 3910 & 1210 & 1804 & 6408 & 4310 & 4500 & 3810 & 1810 & $4020 \pm 2293$ \\
Chrysin & 5726 & 6810 & 2810 & 1820 & 4730 & 6410 & 2301 & 1720 & 5320 & 4230 & 1820 & $3972 \pm 1949$ \\
Pinocembrin & 5205 & 4720 & 6200 & 3601 & 3814 & 5520 & 6420 & 3000 & 4601 & 6000 & 4133 & $4837 \pm 1132$ \\
CAPE & 89 & 230 & 466 & 320 & 55 & 430 & 230 & 90 & 70 & 120 & 204 & $209 \pm 144$ \\
\hline
\end{tabular}

$(-)$ : not detected

\section{DISCUSSION}

Honey is an important food source and an important source of bioactive components. Honey compounds may vary depending on the geographical features of the region of production, the plant flora, the harvest time, and the mode of production (Dżugan et al.
2018). The bioactive properties of honey largely derives from the secondary metabolites it contains, and these are known to be maximally affected by the plant flora (Juszczak et al. 2016, Kaygusuz et al. 2016). Since Anzer honey is produced in a region with a rich plant flora, it is regarded as healthy, with a pleasant taste and aroma. The bioactive 


\section{ARAŞTIRMA MAKALESI / RESEARCH ARTICLE}

components of this honey produced in very limited quantities and sold at very high prices are unknown. The purpose of this study was to perform a biological characterization of Anzer honey's secondary metabolites in particular polyphenolic compositions and associated antioxidant characteristics, and thus both to fill a gap in the scientific literature and also to contribute to bee-keeping in Turkey. Palynological studies revealed that Anzer honey is a blossom honey of the class of hetero floral honeys. The pollen analyses were consistent with the data in the literature (Sorkun et al. 1989).

The purity and naturalness of honey is determined by such parameters as moisture, conductivity, optic rotation, acidity, $\mathrm{pH}$, color value, sugar ratios, HMF, and proline, according to the honey codices (Juszczak et al. 2016, El Sohaimy. 2015). However, the real value of honey is associated with the variety and quantities of the secondary metabolites it contains, and other parameters not used in this study. The variety and quantity of polyphenolic compounds passing through flowers is an important parameter in defining the geographical sign of honey. The polyphenols contained in honey depend on the flora in the region, and these are the essential compounds responsible for the honey's color and taste, sensory characteristics, and biological activity values. Bioactive compounds with phenolic structures, like phenolic acids, flavonoids, and anthocyanin are natural compounds that reduce the risk of oxidative damage in living cells, are capable of scavenging free radicals, reducing inflammation, and activating the immune system (Cianciosi et al. 2018, Manach et al. 2004). The mean total polyphenol content of Anzer honey in the present study was $26.92 \mathrm{mg} \mathrm{GAE} / 100 \mathrm{~g}$, a value consistent with flowers honeys in the literature. The mean total phenolic content of Jerusalem thorn honeys (Karaçalı) collected from the Marmara region of Turkey in our previous study was $53 \mathrm{mg}$ GAE/100g (Malkoç et al. 2019). Another study of monofloral honeys in Turkey reported total polyphenolic contents of $25 \mathrm{mg}$ GAE/100g in clover honey, $16 \mathrm{mg}$ $\mathrm{GA} / 100 \mathrm{~g}$ in acacia honey, $41 \mathrm{mg}$ GAE/100 $\mathrm{g}$ in linden honey, $23 \mathrm{mg} \mathrm{GAE} / 100 \mathrm{~g}$ in rhododendron honey, and $98 \mathrm{mg} \mathrm{GAE} / 100 \mathrm{~g}$ in chestnut honey (Can et al. 2015). The mean total flavonoid content of Anzer honey in this study was $2.79 \mathrm{mgQE} / 100 \mathrm{~g}$, a value higher than those reported for blackthorn, acacia, rhododendron, clover and milk vetch honeys (Can et al. 2015).
The antioxidant capacities of the honeys in this study were measured using the FRAP method. The honeys reduced iron (III) at varying concentrations, and these values ranged between 92 and 124 ( $\mu$ molTrolox/100g) according to the Trolox standard. Honeys' antioxidant values were tested using DPPH, a commercial radical test. The mean DPPH scavenging activity was determined as mean 49.12 $\mathrm{mg} / \mathrm{mL}$. These results show that Anzer honey has greater free radical-scavenging and antioxidant activities than those of numerous honeys cited in the literature (Anand et al. 2018). The antioxidant value of the honey derives from the small quantity of ascorbic acid in its structure and more from the presence of polyphenolic substances. For example, chestnut and oak honeys, regarded as possessing large amounts of polyphenolic substances, have been reported to exhibit DPPH radical neutralizing capacities of $20 \mathrm{mg} / \mathrm{mL}$ and $12 \mathrm{mg} / \mathrm{mL}$, respectively (Can et al. 2015). To summarize, these honeys' reduction capacities vary within a narrow range, the values determined are compatible with the data in the literature, and the honey has a higher antioxidant capacity than many floral honeys

Polyphenolic composition with HPLC-UV revealed that of the Anzer honeys studied contained varying quantities of all phenolic compounds, except for the standard syringic acid and daidzein. Based on mean values, the phenolic substances found at the highest levels were pinocembrin $(4837 \pm 1132 \mu \mathrm{g} / 100 \mathrm{~g})$, hesperidin $(4020 \pm 2293 \mu \mathrm{g} / 100 \mathrm{~g})$, and chrysin $(3972 \pm 1949 \mu \mathrm{g} / 100 \mathrm{~g})$. In this study, phenolic compounds of protocatechuic acid, p-coumaric acid, catechin, CAPE, $p-\mathrm{OH}$ benzoic acid and caffeic acid were detected at moderate levels, myricetin, luteolin, rutin, resveratrol, epicatechin, $t$-cinnamic acid, ferulic acid and gallic acid were detected in minor levels.

These phenolic acids and flavonoids detected in Anzer honeys are important antioxidant and antiinflammatory molecules, and are responsible for the honey's apitherapeutic properties. Hesperidin, pinocembrin, chrysin, coumaric acid, caffeic acid and CAPE are the effective agents of propolis, and their significantly elevated levels in Anzer honey were striking (Huang et al. 2014). Studies have determined that these phenolic compounds possess medical properties. For example, pinocembrin, detected at the highest concentration in Anzer honey, is an important flavonoid with proven pharmacological activity in neurodegenerative and cardiovascular diseases (Nyokat et al. 2017). Hesperedin is a flavonoid largely found in citrus fruits 


\section{ARAŞTIRMA MAKALESI / RESEARCH ARTICLE}

possessing good anti-inflammatory and antioxidant properties (Parhiz et al. 2015, Iranshahi et al. 2015), while chrysin has been reported to be an important anti-tumoral agent (Kasala et al. 2015). The phenolic acids such as protocatechuic acid and caffeic acid are powerful antidiabetic agents (Spiliotiet et al. 2014), p-coumaric acid and caffeic acid reduce oxidative damage caused by hypoxia with their neuroprotective effects (Cruz et al. 2016), and catechin and $p-\mathrm{OH}$ benzoic acid exhibit antioxidant properties by scavenging superoxide radicals (Afroz et al. 2016, Velika and Kron 2012). In addition, the preponderance of the compounds in the honey may use as a promising marker in determining the botanical origins of the honey. For example, quercetin is the main flavonoid compound in sunflower honey, 8-(methoxy) kaempferol in rosemary honey, hesperidin in citrus honey, and naringenin and luteolin in lavender honey (Kaškonienè and Venskutonis 2010).

\section{CONCLUSION}

The results are showed that Anzer honey is a heterofloral blossom honey and contains a wide range variety polyphenolic and flavonoid compounds. The presence of polyphenolic substances increases the medicinal value of honey and provides high antioxidant, antimicrobial and antiinflammatory properties.

\section{REFERENCES}

Afroz, R., Tanvir, E., Little, PJ. 2016. Honey-derived flavonoids: natural products for the prevention of atherosclerosis and cardiovascular diseases. Clinical and Experimental Pharmacology, 6(3).

Anand, S., Pang, E., Livanos, G., Mantri, N. 2018. Characterization of physico-chemical properties and antioxidant capacities of bioactive honey produced from Australian grown Agastache rugosa and its correlation with colour and poly-phenol content. Molecules, 23(1): 108.

Benzie, IF., Strain, JJ. 1996. The ferric reducing ability of plasma (FRAP) as a measure of antioxidant power the FRAP assay. Analytical biochemistry, 239(1): 70-76.
Can, Z., Yıldız, O., Sahin, H., Turumtay, EA., Silici, S., Kolayli, S. 2015. An investigation of Turkish honeys: their physico-chemical properties, antioxidant capacities and phenolic profiles. Food Chemistry, 180, 133141.

Cianciosi, D., Forbes-Hernández, T., Afrin, S., Gasparrini, M., Reboredo-Rodriguez, P., Manna, P., Quiles, J. 2018. Phenolic compounds in honey and their associated health benefits: a review. Molecules,23(9): 2322.

Cruz, LC., Ecker, A., Dias, RS., Seeger, RL., Braga, MM., Boligon, AA., Posser, T. 2016. Brazilian pampa biome honey protects against mortality, locomotor deficits and oxidative stress induced by hypoxia/reperfusion in adult Drosophila melanogaster. Neurochemical research, 41(1-2):116-129.

Çakir, HE., Şirin, Y., Kolayli, S., Can, Z. 2018. Validation methods for phenolic components with RP-HPLC-UV in various bee products. Apiterapi ve Doğa Dergisi, 1(1), 13-19.

Deng, J., Liu, R., Lu, Q., Hao, P., Xu, A., Zhang, J., Tan, J. 2018. Biochemical properties, antibacterial and cellular antioxidant activities of buckwheat honey in comparison to manuka honey. Food chemistry,252,243-249.

Doğan, A., Kolankaya, D. 2005. Protective effect of Anzer honey against ethanol-induced increased vascular permeability in the rat stomach. Experimental and Toxicologic Pathology, 57(2):173-178.

Dżugan, M., Tomczyk, M., Sowa, P., Grabek-Lejko, D. 2018. Antioxidant activity as biomarker of honey variety. Molecules, 23(8): 2069.

El Sohaimy, SA., Masry, SHD., Shehata, MG. 2015. Physicochemical characteristics of honey from different origins. Annals of Agricultural Sciences, 60(2): 279-287.

Fukumoto, LR., Mazza, G. 2000. Assessing antioxidant and prooxidant activities of phenolic compounds. Journal Agriculture Food Chemistry, 48, 3597-3604.

Huang, S., Zhang, CP., Wang, K., Li, GQ., Hu, FL. 2014. Recent advances in the chemical composition of propolis. Molecules, 26;19(12):19610-32. 


\section{ARAŞTIRMA MAKALESI / RESEARCH ARTICLE}

Iranshahi, M., Rezaee, R., Parhiz, H., Roohbakhsh, A., Soltani, F. 2015. Protective effects of flavonoids against microbes and toxins: The cases of hesperidin and hesperidin. Life sciences, 137, 125-132.

Juszczak, L., Gałkowska, D., Ostrowska, M., Socha, R. 2016. Antioxidant activity of honey supplemented with bee products. Natural product research,30(12), 1436-1439.

Kara, M., Sezgin, E., Kara, A. 2012. İmportance of caucasian honeybee and its characteristics as a gene resource. Journal of Agricultural Science and Technology. A, 2(10A):1197.

Kasala, ER., Bodduluru, LN., Madana, RM., Gogoi, R., Barua, CC. 2015. Chemopreventive and therapeutic potential of chrysin in cancer: mechanistic perspectives. Toxicology letters, 233(2): 214-225.

Kaškonienè, V., Venskutonis, PR. 2010. Floral markers in honey of various botanical and geographic origins: a review. Comprehensive reviews in food science and food safety, $9(6)$ : 620-634.

Kaygusuz, H., Tezcan, F., Erim, FB., Yildiz, O., Sahin, H., Can, Z., Kolayli, S. 2016. Characterization of Anatolian honeys based on minerals, bioactive components and principal component analysis. LWT-Food Science and Technology, 68, 273-279.

Korkmaz, A., Kolankaya, D. 2009. Anzer honey prevents $\mathrm{N}$-ethylmaleimide-induced liver damage in rats. Experimental and Toxicologic Pathology, 61(4): 333-337.

Louveaux, J., Maurizio, A., Vorwohl, G. 1978. Methods of melissopalynology. Bee World, 59(4):139-157.

Malkoç, M., Kara, Y., Özkök, A., Ertürk, Ö., Kolayli, S. 2019. Karaçalı (Paliurus spina-christi Mill.) balının karakteristik özellikleri. Uludağ Arıcılık Dergisi, 19(1): 69-81.

Manach, C., Scalbert, A., Morand, C., Rémésy, C., Jiménez, L. 2004. Polyphenols: food sources and bioavailability. The American journal of clinical nutrition, 79(5): 727-747.

Molyneux, P. 2004. The use of the stable free radical diphenylpicrylhydrazyl (DPPH) for estimating antioxidant activity. Songklanakarin J. Sci. Technol, 26(2): 211-219.
Nyokat, N., Yen, K H., Hamzah, AS., Lim, IF., Saaidin, AS. 2017. Isolation and synthesis of pinocembrin and pinostrobin from Artocarpus odoratissimus. Malaysian Journal of Analytical Sciences, 21(5), 1156-1161.

Parhiz, H., Roohbakhsh, A., Soltani, F., Rezaee, R., Iranshahi, M. 2015. Antioxidant and antiinflammatory properties of the citrus flavonoids hesperidin and hesperidin: an updated review of their molecular mechanisms and experimental models. Phytotherapy Research, 29(3), 323-331.

Singleton, VL., Rossi, JA. 1965. Colorimetry of total phenolics with phosphomolybdicphosphotungstic acid reagents. American journal of Enology and Viticulture, 16(3):144158.

Sorkun, K., Güner, A., Vural, M. 1989. Rize ballarında polen analizi. Doğa TU Botanik $D, 13(3)$ : 547-554.

Spilioti, E., Jaakkola, M., Tolonen, T., Lipponen, M., Virtanen, V., Chinou, I., Moutsatsou, P. 2014. Phenolic acid composition, antiatherogenic and anticancer potential of honeys derived from various regions in Greece. PloS one, 9(4), e94860.

Şekeroğlu N., Deveci, M., Buruk, CK., Gürbüz, B., İpek, A. 2007. Chemical composition and antimicrobial activity of Anzer tea essential oil. Journal of the Science of Food and Agriculture, 87(7):1424-1426.

Tezcan, F., Kolayli, S., Sahin, H., Ulusoy, E., Erim, B. 2011. Evaluation of organic acid, saccharine composition and antioxidant properties of some authentic Turkish honeys. Journal of Food and Nutrition Research, 50(1):33-40.

Vasić, V., Gašić, U., Stanković, D., Lušić, D., VukićLušić, D., Milojković-Opsenica, D., Trifković, J. 2019. Towards better quality criteria of European honeydew honey: Phenolic profile and antioxidant capacity. Food chemistr, 274, 629-641.

Velika, B., Kron, I. 2012. Antioxidant properties of benzoic acid derivatives against superoxide radical. Free Radicals and Antioxidants, 2(4): 62-67. 